Steroids in Arms:

\title{
Science, Government, Industry, and the Hormones of the Adrenal Cortex in the United States, 1930-1950
}

\author{
NICOLAS RASMUSSEN*
}

Experimental life science in the twentieth century is aptly characterized as a quest for "master molecules", biochemical entities presumed to govern all basic vital processes and phenomena. Today many commentators critique the reigning "genetic essentialism"- the notion that everything about the life of human beings (and other living things) is predetermined in their DNA, today's master molecule. ${ }^{1}$ However, notwithstanding efforts by early geneticists to promote the gene, present fashion must not make us forget that in the first half of the twentieth century, hormones took pride of place as life's master molecules, and the endocrinologist took precedence over the geneticist as the scientist offering the means to control life. For such are the inherent implications of master molecules: to discover and manipulate these substances is to acquire the means to control the vital processes and phenomena governed by them. The master molecule thus constitutes an intersection between intellectual, therapeutic, and commercial interests, naturally attracting the most ambitious participants in biomedical science and industry. And indeed, many ethical pharmaceutical companies in the inter-war era-driven in the United States and

* Nicolas Rasmussen, BA, MA, MPhil, PhD,
School of Science and Technology Studies, LG 13
Morven Brown Building, University of New
South Wales, Sydney, NSW 2052, Australia.
The author would like to acknowledge the
assistance of archivists at the National Archives
of the United States, Princeton University, and
the University of Pennsylvania, as well as the
comments of colleagues at the Office of History
of Science and Technology, University of
California, Berkeley, where much of the research
was carried out, and at the University of New
South Wales, where final stages of the research
and writing took place. Special thanks are due to
Rachel Ankeny, Harry Marks, Peter Neushul,
Bob and Mary Joe Nye, and Leo Slater for
contributing important insights and helpful
information, and to the referees of the
manuscript for further good advice. This work
was funded by the National Science Foundation
under grant SES 9729131 , whose support during his period as an independent scholar is most gratefully appreciated.

${ }^{1}$ E F Keller, 'The force of the pacemaker concept in theories of aggregation in cellular slime mold', Perspect. Biol. Med., 1983, 26: 515-21; idem, 'Physics and the emergence of molecular biology: a history of cognitive and political synergy', J. Hist. Biol., 1990, 23: 389-409; Lily Kay, 'Problematizing basic research in molecular biology', in Arnold Thackray (ed.), Private science, Philadelphia, University of Pennsylvania Press, 1998, pp. 20-38. For critiques and histories of genetic essentialism, see Richard Lewontin, The doctrine of DNA: biology as ideology, New York, Harper, 1992; Diane Paul, Controlling human heredity: 1865 to the present, Atlantic Highlands, NJ, Humanities Press, 1995; Dorothy Nelkin and M Susan Lindee, The DNA mystique: the gene as a cultural icon, New York, Freeman, 1995. 


\section{Nicolas Rasmussen}

other countries by a medical profession eager to shed old nostrums for new remedies bearing the stamp of laboratory science-did bring a remarkable variety of (comparatively) pure hormone preparations to market for an even more remarkable range of clinical indications. In the process, drug firms avidly supported the hormone research of leading physiologists and biochemists, forging new ties between academic life science and biomedical industry that helped shape the future development of pharmaceuticals. ${ }^{2}$ Since the power and promise extravagantly attributed to genes today echo those surrounding hormones half a century ago (not to mention the advantages and drawbacks of the scientist-industrialist collaborations created to harness the power of life's master molecules), we may have much to learn from studying earlier endocrinological dreams.

To help recapture the heady atmosphere of medical, scientific and commercial enthusiasm surrounding hormones in the first half of the twentieth century, and the scientist-industrialist collaborations it spawned, in the following essay I trace Edward C Kendall's research on the hormones of the adrenal cortex in the 1930s and 1940s. This story illustrates well all three aspects of endocrine research in the period noted above: the nearly unlimited power over life processes ascribed to hormones; the immense medical and commercial promise perceived to lie in hormones; and the intimate interactions between top-level life scientists and the drug industry in the inter-war period generated by the effort to bring hormone therapeutics to market, which continued right through the war despite the strong involvement of government science agencies. Because the concluding part of the story, in which the American government organized and sponsored a crash programme to develop the cortical hormones as performance-enhancing drugs for combat pilots, may throw new light on the nature of state management of life science and industry during the war, it will be treated in particular detail. I argue that, in this field of biomedicine at least, the discontinuities in the practice of research introduced by war were not so great as envisioned by commentators who see the Second World War as a watershed for American science, proposing, for instance, that the larger government-sponsored projects set new precedent by "transgressing and reshaping" "boundaries ... between public knowledge and private profit" and bringing "Big

\footnotetext{
${ }^{2}$ John P Swann, Academic scientists and the pharmaceutical industry: cooperative research in twentieth-century America, Baltimore, Johns Hopkins University Press, 1988; Jonathan Liebenau, Medical science and medical industry: the formation of the American pharmaceutical industry, Baltimore, Johns Hopkins University Press, 1987. On hormone drug development see Alison Li, 'J. B. Collip, A. M. Hanson and the isolation of the parathyroid hormone, or endocrines and enterprise', J. Hist. Med. Allied Sci., 1992, 47: 405-38; Michael Bliss, The discovery of insulin, University of Chicago Press,
}

\author{
1982; Nelly Oudshoorn, Beyond the natural body: \\ an archaeology of sex hormones, London, \\ Routledge, 1994. For an historical perspective on \\ biological projects to control life, see also Philip \\ Pauly, Controlling life: Jacques Loeb and the \\ engineering ideal in biology, New York, Oxford \\ University Press, 1987. See also Nicolas \\ Rasmussen, 'Biotechnology before the "biotech \\ revolution": life scientists, chemists and product \\ development in 1930s-1940s America', in Carsten \\ Reinhart (ed.), Chemical sciences in the 20th \\ century: bridging boundaries, Weinheim, \\ Wiley-VCH, 2001, pp. 201-27.
}


Science" to life science as well as physics. ${ }^{3}$ On the contrary, the scientific, medical and commercial promise of the master molecules had already made endocrinology into "Big Science" before the war, and wartime government involvement in the field did little to change this.

\section{The Hormone Business in America, 1900-1930}

From the late nineteenth century to the 1940s, endocrinology was one of the most dynamic areas of biomedical research, despite a certain aura of quackery that gathered around the field in its earliest years, generated precisely by its perceived promise (which provoked a proliferation of unrefined organ extract treatments for popular ailments such as impotence and hysteria). Together with bacteriology, endocrinology was one of the first areas in which the life sciences established their direct utility in clinical medicine, with the milestone 1891 demonstration that extract of thyroid glands was effective in treating the well-defined clinical deficiency condition myxoedema. By the 1920s, a high calibre of laboratory research had elevated the stature of the field, and a standard pattern for hormone research programmes had coalesced. Typically, a deficiency condition was created in an experimental animal (ideally, a condition with clear similarities to a human disease) by surgical removal of an endocrine organ, and then chemical extracts of the organ were prepared from slaughterhouse waste or other abundant sources and tested for their capacity to remedy the experimental animals' condition. Testicular extract was tested for its ability to promote comb growth in capons, for example, and pancreatic extract for its ability to prevent diabetic symptoms in dogs whose pancreas had been excised. Once a preparation procedure was developed that yielded extracts active in treating the deficiency condition of the experimental animals, efforts turned to concentrating and purifying the active compound(s) by chemically fractionating the organ extract,

\footnotetext{
${ }^{3}$ Derek De Solla Price, Little science, big science ... and beyond, New York, Columbia University Press, 1986. For a sample of the classic literature on the Second World War and the changes it brought to physical sciences, see A Hunter Dupree, 'The great instauration of 1940: the organization of scientific research for war', in Gerald Holton (ed.), The twentieth century sciences: studies in the biography of ideas, New York, Norton, 1972, pp. 443-67; contributions in Paul Forman and José M Sánchez-Ron (eds), National military establishments and the advancement of science and technology, Dordrecht, Kluwer, 1996; and contributions in Peter Galison and Bruce Hevly (eds), Big science: the growth of large-scale research, Stanford University Press, 1992; see also James Capshew and Karen Rader, 'Big science: price to the present', Osiris, 1992, 7: 3-25; Daniel Kevles, The physicists: the history of a scientific community in modern America, New
}

\begin{abstract}
York, Knopf, 1978; Paul Forman, 'Behind quantum electronics: national security as basis for physical research in the United States, 1940-1960', Historical Studies in the Physical and Biological Sciences, 1987, 18: 149-229; and Nathan Reingold, 'Science and government in the United States since 1945', Hist. Sci., 1994, 32: 361-86. On life sciences during and after the Second World War treated according to the same model, see, for example, Jean-Paul Gaudillière, 'The molecularization of cancer etiology in the postwar United States: instruments, politics and management', in Soraya de Chadarevian and Harmke Kamminga (eds), Molecularizing biology and medicine: new practices and alliances, 1910s-1970s, Amsterdam, Harwood, 1998, pp. 139-70; and Angela Creager, 'Biotechnology and blood: Edwin Cohn's plasma fractionation project, 1940-1953', in Thackray, op. cit., note 1 above, pp. 39-62, quotes on pp. 41,44 .
\end{abstract}




\section{Nicolas Rasmussen}

at every step using bio-assay with the experimental animals to detect the fraction containing hormone activity. Success was marked by crystallization of a pure, highly active compound presumed to be the native hormone on the basis of its full substitution, in the experimental animals, for the gland removed. Analysis of the hormone's chemical structure and properties followed, and, if technologically feasible, the analysis would be confirmed by chemically synthesizing a compound of the proposed structure and showing the synthetic material to have hormone activity identical to natural organ extracts in the standard bio-assay. The growing chemical sophistication of endocrinology research brought biochemists into ever-closer collaborations with physiologists, or else into physiological research themselves. Indeed, such work in endocrinology was a major driving force in the development of biochemical methods, and in the rising status of biochemistry, during the first decades of the twentieth century. ${ }^{4}$

The typical trajectory of hormone research just outlined constituted not only a programme for the advancement of biomedical knowledge during the inter-war years, but simultaneously a plan for commercial drug development. As noted, from the earliest days of endocrinology, more or less active extracts of a variety of organs were marketed for use by physicians: most notoriously testes extracts for the treatment of flagging virility, but also extracts of ovaries, pancreas, thyroid glands, and adrenals. From 1897 to 1901, the blood-pressure-raising hormone epinephrine was isolated from adrenal glands, and was quickly brought to market in relatively pure form with great success by Parke-Davis Company, under its trade name "Adrenaline". In 1915 , chemically pure thyroid hormone highly active in treatment of myxoedema was isolated, and soon found its way into the marketplace for a variety of conditions. ${ }^{5}$ The 1922 advent of insulin, saving millions of diabetics from the prospect of early and lingering deaths, vividly confirmed the medical and commercial potential of endocrinology, and raised the competitive tempo of the field. The drug had been developed through a mutually profitable collaboration between the Eli Lilly firm and the University of Toronto, site of the crucial research on isolating the pancreatic hormone. Lilly's spectacular success brought many other drug companies into closer collaboration with enterprising endocrinologists in an effort to repeat the insulin

\footnotetext{
${ }^{4}$ On the pattern of scientific investigation into the active principles of the endocrine glands to the early 1920s, see W F Bynum, "C'est un malade": animal models and concepts of human diseases', J. Hist. Med. Allied Sci., 1990, 45: 397-413; Leonard Wilson, 'Internal secretions in disease: the historical relations of clinical medicine and scientific physiology', J. Hist. Med. Allied Sci., 1984, 39: 263-302; Li, op. cit., note 2 above; Oudshoorn, op. cit., note 2 above. On endocrinology and the advance of biochemistry in the first half of the twentieth century, see Robert Kohler, From medical chemistry to biochemistry: the making of a biomedical discipline, Cambridge University Press, 1982; and V C Medvei, The history of clinical endocrinology, Pearl River, NY, Parthenon, 1993.
}

\footnotetext{
${ }^{5}$ On the development and early use of adrenal extracts to treat Addison's disease, see George W Thorn, 'The adrenal cortex. I. Historical aspects', Johns Hopkins med. J., 1968, 123: 49-64. On thyroid hormone, see below, and also E C Kendall, Thyroxine, New York, published for the American Chemical Society by Chemical Catalog Co., 1929. On adrenalin, see John Parascandola, The development of American pharmacology: John $J$ Abel and the shaping of a discipline, Baltimore, Johns Hopkins University Press, 1992, pp. 57-8, and passim; Horace Davenport, 'Epinephrin(e)', Physiologist, 1982, 25: 76-82; E M Tansey, 'What's in a name? Henry Dale and adrenaline, 1906', Med. Hist., 1995, 39: 459-76.
} 
story with the hormones of other organs, and even spurred the establishment of whole new endocrine firms, such as Organon in Holland. In these growing collaborations between pharmaceutical companies and academic life scientists in hormone research (and in the neighbouring field of vitamins), drug firms sought access to novel scientifically validated therapeutics, and the scientists garnered material assistance for their research. The level of hormonal enthusiasm among drug firms and enterprising scientists prompted at least one contemporary commentator to describe this situation in endocrinology of the 1920s and 1930s as a "gold rush".

On both the biochemical and commercial fronts of endocrinology, Edward C Kendall of the Mayo Clinic and Foundation could safely be described as a trailblazer. For three years after his 1910 Columbia University doctorate in chemistry, received at the age of twenty-four for work on a starch-degrading enzyme isolated from pancreas, Kendall had struggled against a widespread attitude of physicians and drug firms alike that biochemists were suited only to service roles. Finding a haven at the Mayo Clinic in 1914 as head of that institution's new biochemistry section, Kendall proved his vision that biochemical research could advance practical therapeutics with the crystallization of the thyroid hormone, named "thyroxine" by him, within his first year there. The discovery was trumpeted in the press as a medical triumph, bringing prestige to the Mayo and elevating Kendall's scientific reputation. In 1916, well before his definitive 1919 paper on the chemical attributes of thyroxine, Kendall had patented his thyroid hormone preparation method and assigned this intellectual property to the University of Minnesota, which had affiliated with the Mayo Clinic when the two entities jointly established the Mayo Foundation in 1915 as a (non-profit) teaching institution of the University's medical school. In 1919, the University granted an exclusive licence for use of Kendall's patent to the Squibb pharmaceutical firm in exchange for 50 per cent of profits from the product, which Squibb successfully marketed. Kendall's thyroxine and other less pure thyroid hormone preparations became popular drugs in the inter-war years, not just for myxoedema and other hypothyroid conditions, but also, because of their general metabolism-stimulating effects, for a wide range of disorders including constipation, menstrual disorders and even for weight control in "those who enjoy food to the extent that obesity is preferable to self-denial". ${ }^{7}$

\footnotetext{
${ }^{6}$ David Hamilton, The monkey gland affair, London, Chatto \& Windus, 1986; Merriley Borell, 'Brown-Séquard's organotherapy and its appearance in America at the end of the nineteenth century', Bull. Hist. Med., 1976, 50: 309-20; Nelly Oudshoorn, 'United we stand: the pharmaceutical industry, laboratory, and clinic in the development of sex hormones into scientific drugs, 1920-1940', Science, Technology and Human Values, 1993, 18: 5-24; Tom Mahoney, The merchants of life: an account of the American pharmaceutical industry, New York, Harpers, 1959, pp. 73-4; Wilson, op. cit., note 4 above; E C Kendall, Cortisone: memoirs of a hormone hunter, New York, Scribners, 1971, ch. 4; Robert Tattersall, 'Pancreatic organotherapy for diabetes,
}

1889-1921', Med. Hist., 1995, 39: 288-316; Bliss, op. cit., note 2 above; Swann, op. cit., note 2 above, ch. 5; Li, op. cit., note 2 above; Davenport, op. cit., note 5 above; Oudshoorn, op. cit., note 2 above, p. 88 , where she quotes from the biologist Robert Frank's The female sex hormone, Baltimore, Charles C Thomas, 1929.

${ }^{7}$ On the history of the Mayo Clinic, see Lucy Wilder, The Mayo Clinic, Rochester, MN, Lucy Wilder Books, 1936. On thyroid hormone research and development, see Kendall, op. cit., note 6 above, ch. 4; idem, 'The isolation in crystalline form of the compound containing iodine, which occurs in the thyroid, its chemical nature and physiologic activity', J. Am. med. Ass., 1915, 64: 2042-3; idem, 'Isolation of the 


\section{Nicolas Rasmussen}

The royalties to the University of Minnesota from Kendall's thyroxine patent were placed in a special fund for Kendall to draw on for research expenditures. This arrangement seems to have satisfied all parties, and was widely considered a success, representing, perhaps, the triumph of the utilitarian ethic of chemists over the Hippocratic ideals of physicians. In 1922, when Toronto physiologist J J R Macleod sought Kendall's advice on whether to patent the insulin preparation procedure developed by Frederick Banting, Charles Best, and James Collip in his laboratory, Kendall explained the thyroxine arrangements, and offered Macleod his business and ethical advice as well ("I can see no more reason why the man that separates the active constituent of the pancreas should not share financially as much as the man that makes a new wireless telephone"). As noted, the Toronto group did patent their insulin production method, granting Lilly an exclusive licence for a limited period to compensate the firm for its investment in the development of the drug. The biochemist Harry Steenbock of the University of Wisconsin also emulated Kendall, establishing a separate foundation when the University refused to manage his vitamin D preparation patent directly. ${ }^{8}$ Kendall's thyroxine invention and patent arrangements served as a paradigm of entrepreneurial life science in the inter-war period, showing how a medical investigator might benefit his own research and his institution, while at the same time benefiting mankind by ensuring that his discovery was manufactured and distributed by a reputable drug firm, in conformity with the highest quality standards.

\section{The Biochemist-Entrepreneur Faces the Great Depression}

For several years after his decade-long quest to prove the structure he had proposed for thyroxine was foiled by a competitor in 1926, Kendall's research wandered among several short-term projects. However, in 1930 he set his sights on a new major objective: purifying and characterizing the hormone of the adrenal cortex, with an eye to discovering a commercially feasible production method along the way. Belief in an essential hormone of the adrenal cortex, as opposed to the adrenal medulla from which epinephrine had been isolated at the turn of the century, was surprisingly new at this point. It was not until the late 1920s that accumulating evidence began to convince the medical profession that epinephrine was not an effective treatment of Addison's disease, the deadly condition caused by acute adrenal insufficiency, and

iodine compound which occurs in the thyroid', J. Biol. Chem., 1919, 39: 125-47; idem, Thyroxine, note 5 above. Also, the 1919 (otherwise n.d.) licensing agreement between the University of Minnesota and Squibb regarding U.S. patent application 102,302 of 7 June 1916, carton 8, folder 'Patents--Thyroxin', E C Kendall Papers, Princeton University Archives collection c0669 (henceforward, Kendall Papers). For the uses to which thyroid hormone was put in the inter-war years, see medical textbooks of the time, e.g. Louis Goodman and Alfred Gilman, The pharmacological basis of therapeutics, New York, Macmillan, 1941, pp. 1156-69, quote on p. 1168.

${ }^{8}$ Bliss, op. cit., note 2 above, pp. 132-3. On Steenbock, see Rima Apple, 'Patenting university research: Harry Steenbock and the Wisconsin Alumni Research Foundation', Isis, 1989, 80: 375-94. For a brief contemporary account of the medical patent situation, see Morris Fishbein, 'Medical patents', J. Am. med. Ass., 1937, 109: $1539-43$. 


\section{Steroids in Arms}

thus that a different hormone from the adrenal cortex might be involved. Between 1927 and 1930 several physiologists confirmed that adrenal extracts could indefinitely sustain otherwise short-lived adrenalectomized dogs and cats, suggesting that such animals could be used as a bio-assay for cortical hormone activity. ${ }^{9}$ These physiological findings coincided with the Mayo visit, from late 1929 to early 1930, of the eminent biochemist Albert Szent-Györgyi, pursuing the isolation of vitamin $\mathbf{C}$ from adrenal glands obtained from slaughterhouses in nearby St Paul. Szent-Györgyi familiarized Kendall with work on the adrenal while there, and left behind some large meat presses and other preparatory equipment. From his earlier thyroxine triumph, Kendall was, of course, generally adept at the art of purifying scarce hormones from ground animal tissue. Thus in terms of timing as well as local intellectual and material resources, novel adrenal hormones emerged as especially opportune scientific targets for Kendall in 1930. Moreover, Mayo's chief of medicine, the physiologist and physician Leonard Rowntree, was conducting clinical research on Addison's disease, and was eager to enlist Kendall's help in making adrenal extracts so that he might try the new treatment on the many terminal Addison's patients he had accumulated at the Mayo. Naturally, in the darkest days of the Depression, biochemistry research with such direct clinical applicability was easiest to justify at a resource-strapped medical institution. Thus a confluence of scientific and social circumstances led Kendall quickly to refocus almost all his research on the adrenal cortex. ${ }^{10}$

Unfazed by his late start and by inevitable setbacks, including one premature claim to have isolated and chemically identified the hormone of the adrenal cortex which turned out to be an impurity from the benzene used in his extraction process, in early 1934 Kendall became the first to achieve crystallization of a hormone capable of maintaining adrenalectomized animals. Kendall thus pushed to the forefront in a crowded contest to bring a cortical hormone to the medical marketplace, a race which included among the more formidable contenders the physiologist W W Swingle and his collaborators at Princeton, the pharmacologist Arthur Grollman of Johns Hopkins, the Ohio State group of physiologist Frank Hartman (one of the 1927 discoverers of active adrenal extracts), and the biochemists Osker Wintersteiner and J J Pfiffner (earlier of Swingle's group) at Columbia University. As early as 1931,

\footnotetext{
${ }^{9}$ See O Brenner, 'Addison's disease with atrophy of the cortex of the suprarenals', Q. J. Med., 1928, 22: 121-44; J M Rogoff and G N Stewart, 'The influence of adrenal extracts on the survival period of adrenalectomized dogs', Science, 1927, 66: 327-8; idem, 'Studies on adrenal insufficiency. IX. The influence of extracts of adrenal cortex (sheep and cattle) on the survival period of adrenalectomized dogs and cats', Am. J. Physiol., 1929, 91: 254-66; F A Hartman, C G Macarthur and W E Hartman, 'A substance which prolongs the life of adrenalectomized cats', Proc. Soc.
}

exp. Biol. Med., 1927, 25: 69-79; F A Hartman and $\mathrm{K} A$ Brownell, 'The hormone of the adrenal cortex', Science, 1930, 72: 76; W W Swingle and J J Pfiffner, 'The revival of comatose adrenalectomized cats with an extract of the adrenal cortex', Science, 1930, 72: 75-6. On the confusion between the effects of epinephrine and the hormones of the adrenal cortex, see Thorn, op. cit., note 5 above, and Robert Tattersall, 'Hypoadrenia or "a bit of Addison's disease"', Med. Hist., 1999, 43: 450-67.

${ }^{10}$ Kendall, op. cit., note 6 above, ch. 6. 


\section{Nicolas Rasmussen}

Kendall had been deliberately developing extraction methods for cortical hormones which simultaneously permitted good recovery of epinephrine from the adrenal medulla, in order that sale of this by-product might defray a major part of the expenses of his research programme. In the wake of his crystallization breakthrough and the increased standing it brought, in 1934 Kendall approached the president of Parke-Davis, which (as noted above) had built a lucrative trade in its name-brand "Adrenaline" preparation, with a proposition to supply the firm with epinephrine on an industrial scale in exchange for a continuous supply of adrenal glands. ParkeDavis agreed to provide 500 pounds per week of fresh frozen adrenals to Kendall's laboratory at the Mayo if Kendall would deliver epinephrine in the quantity normally yielded, and meeting the firm's standards of purity. Epinephrine exceeding the expected yield could be sold for cash by Kendall. In order to hedge against possible costs incurred if he were not to meet his yield benchmark, the enterprising Kendall struck another bargain with Wilson Laboratories of Chicago, a pharmaceutical subsidiary of the Wilson meat-packing firm which produced therapeutic organ preparations. Wilson agreed to provide 300 pounds per week of fresh frozen adrenals in exchange for standardization of the potency of the firm's cortical extracts by Kendall's Mayo group, which had refined the relevant bio-assays to a high degree. Kendall tripled his technical staff so he could keep what he aptly called his "pilotplant factory" running around the clock in three 8-hour shifts, six days per week, and his laboratory continued work on this scale for some thirteen years, processing nearly two tons of adrenal glands per month when operating at capacity. ${ }^{11}$ Kendall soon became the chief source of purified cortical hormones in North America, and Mayo the leading site for clinical treatment of adrenal insufficiency, although cruder commercial extracts were available to clinicians everywhere.

Patients suffering acute Addison's disease present some of the following symptoms: mental fatigue, a sense of weakness accompanied by measurable decline in aerobic capacity and muscle strength, loss of appetite and wasting, declining blood volume and flow rate associated with excess sodium excretion through the kidneys together with potassium and urea retention in the blood. Death often comes when these symptoms culminate in circulatory collapse. However, treatment of the comparatively uncommon Addison's disease, which was growing ever rarer with the decline of its chief cause, tuberculosis, does not suffice to explain the high level of scientific and commercial interest in the hormones of the adrenal cortex. Many doctors and physiologists reasoned that even in patients with functional adrenal glands, Addison's-like symptoms such as muscular weakness, mental fatigue, or reduced resistance to cold might be alleviated by cortical hormone therapy. And in short order after the invention and 1931 commercial introduction of cortical extracts

${ }^{11} \mathrm{E}$ C Kendall, 'A study of the suprarenal gland', Proc. Staff Meetings Mayo Clinic, 1931, 6: 296; idem, 'Studies on experimental suprarenal deficiency: a demonstration', Proc. Staff Meetings Mayo Clinic, 1932, 7: 595-6; idem, 'Chemical nature of the hormone of the suprarenal cortex essential to life', Proc. Staff Meetings Mayo
Clinic, 1933, 8: 392-5; E C Kendall, H L Mason, B F McKenzie, C S Myers, and G A Koelsche, 'Isolation in crystalline form of the hormone essential to life from the adrenal cortex', Proc. Staff Meetings Mayo Clinic, 1934, 9: 245-8;

Kendall, op. cit., note 6 above, chs 6-7, quote on p. 62 . 


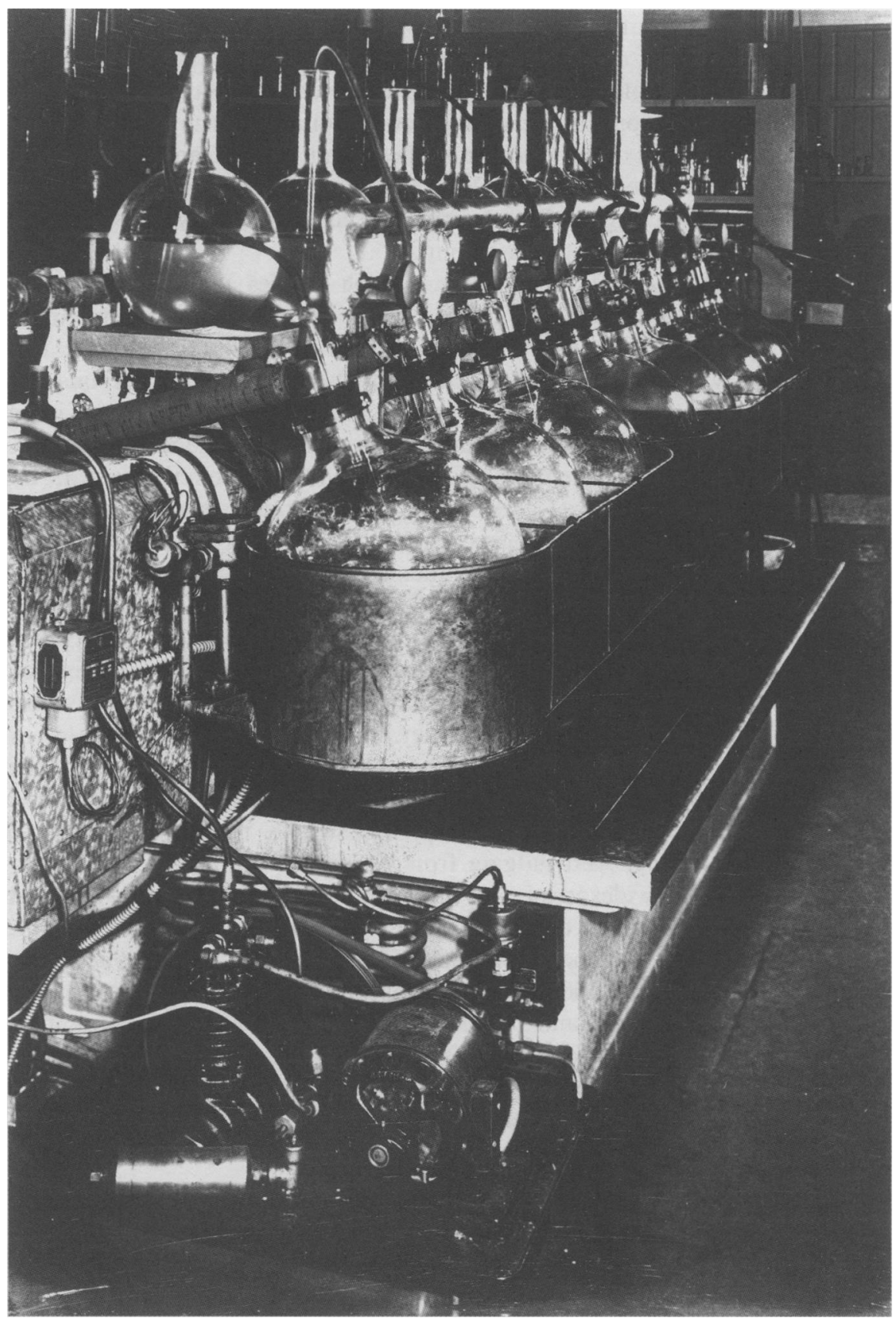

Figure 1: Part of the "pilot plant factory" for extracting hormones from adrenal glands in E C Kendall's laboratory, Mayo Clinic, mid-1930s. Processing capacity was at least 800 pounds of beef adrenals per week. (Princeton University Library, E C Kendall Papers. Manuscripts Division.) 


\section{Nicolas Rasmussen}

effective in relieving the distress of Addison's patients, a raft of animal studies and clinical reports did appear confirming all these same effects in relatively healthy (non-adrenalectomized, non-Addisonian) organisms and people. With cortical hormone injections, normal dogs were found to run much longer on treadmills, "neurotic" but otherwise normal sheep were calmed, and non-Addisonian patients reported increased vitality, lifting of depression, improved digestion and sharper vision. Some striking results in treating muscular dystrophy and schizophrenia were even reported. ${ }^{12}$

Proudly reviewing the first generation of such studies that had followed the discovery of the hormone he had dubbed "cortin" at a meeting of the American College of Physicians in February 1933, Hartman stressed the evidence for the substance's activity in counteracting weakness and "asthenia" of the nervous system, the muscular system, and the circulatory system, as well as certain other physiological problems such as "gastrointestinal instability" and low resistance to disease. Of course, Addison's patients suffered such problems, but Hartman's main argument was that marginal insufficiency of cortical function could underlie many similar complaints in patients with intact adrenals, and thus that cortical hormone might be a widely effective therapeutic. Since "asthenias which are unaccounted for by any known cause can be treated with cortin without harm", it was sensible for a physician to try a course of cortical extract injection on any patient complaining of irritability, fatigue, indigestion, impaired sexual function, insomnia-or simply feeling "below par"-in order to cure the complaint. If a patient responded, the cause of the condition must have been adrenal insufficiency. ${ }^{13}$ Cortical extracts proliferated in the marketplace. For example, Harrower Laboratories offered one called "AdrenoSpermin", advertising that since "stress-emotional, toxic, infective-must involve the endocrines", these glands, and the body as a whole, needed stimulation with cortical hormone therapy. And judging from some contemporary criticism of the "tendency toward the widespread and indiscriminate administration of cortical extract in small and infrequent doses to all those who are "weary and heavy laden" ", such products based on Hartman's way of thinking became popular among the lay public and physicians in the mid-1930s. Expectations that if cortical hormone could improve strength, endurance, and circulation in acute Addison's patients it might do the same in relatively healthy people, scientifically ill-founded as they may have been, certainly help to explain the degree of interest in the hormone for both the medical profession and the pharmaceutical industry. Indeed, the discovery that Addison's patients could be kept alive on a controlled high-sodium, low-potassium

\footnotetext{
${ }^{12} \mathrm{E}$ Eagle, S W Britton, and $\mathrm{R}$ Kline, 'The influence of cortico-adrenal extract on energy output', Am. J. Physiol., 1932, 102: 707-13; F A Hartman and G W Thorn, 'The effect of cortin in asthenia', Proc. Soc. exp. Biol. Med., 1931, 29: 48-50; Ralph Mendelson, 'Cortin in the treatment of progressive muscular dystrophy', J. Am. med. Ass., 1934, 102: 604; R $\mathrm{G}$ Hoskins and $\mathrm{H}$ Freeman, 'The effects of
}

glycerin extract of suprarenal cortex potent by mouth on schizophrenic patients', Endocrinology, 1933, 17: 29-35. For neurotic sheep, see F A Hartman, 'Studies on the function and clinical use of cortin', Ann. Int Med., 1933, 7: 6-22, p. 7.

${ }^{13}$ Hartman, op. cit., note 12 above, p. 18 , for sex drive, insomnia, and "below par" feeling, see p. 8. 


\section{Steroids in Arms}

diet with only occasional cortical extract did little to reduce interest in the hormone, confirming that the treatment of Addison's disease was not the driving force behind these projects. $^{14}$

The industrial scale of his hormone purification effort served Kendall well not only in his race with local competitors, but also with his outstanding European rival, the chemist Tadeus Reichstein of Switzerland. Reichstein was collaborating with Organon, which from Holland supplied the large batches of adrenal extracts that served as the essential raw material of all such research, and in return received Reichstein's patents for improved extract preparation methods. In addition, the Amsterdam group of Organon's co-founder, the physiologist Ernst Laqueur, collaborated with Reichstein by handling bio-assay work on the hormone preparations. Laqueur's research group, and all the others involved, each used different assays to gauge the activity of their cortical preparations. For example, some researchers favoured rate of weight gain in adrenalectomized juvenile rats as an index of cortical hormone activity; some a restoration of glycogen stores in the liver of adrenalectomized rats or other animals; some favoured reduction of increased blood urea levels in adrenalectomized dogs; some used the capacity of adrenalectomized rats to swim. Kendall relied upon the capacity of a muscle in an immobilized, anaesthetized, adrenalectomized rat to perform work over hours or even days, together with a test employed by most groups, the dose required to support adrenalectomized dogs (Kendall's dogs, however, were individually "calibrated" with carefully controlled diets and known sensitivity to cortical extracts). ${ }^{15}$ Thus each of the bio-assays measured cortical hormone activity by improvements in physiological indicators corresponding to particular Addison's-like symptoms in animals with "experimental adrenal insufficiency" (i.e. total adrenalectomy): those measuring blood nitrogen and electrolyte concentrations primarily gauged what Hartman called "circulatory asthenia"; those measuring glycogen stores and activity performance gauged Hartman's "neuro-muscular asthenia". And within these two general classes of assays, procedures differed more or less subtly among the laboratories.

The level of competition in the race to identify and produce the cortical hormone, together with the variety of assays employed by this research community, had led

\footnotetext{
${ }^{14}$ Adreno-Spermin advertisement in $\mathrm{Am}$. J. med. Sci., November 1935, 189: 11. G A Harrop, Albert Weinstein, L J Soffer, and J H Threscher, 'The diagnosis and treatment of Addison's disease', J. Am. med. Ass., 1933, 100: 1850-5; R F Loeb, 'The effect of sodium chloride in treatment of patients with Addison's disease', Proc. Soc. exp. Biol. Med., 1933, 30: 808-12; idem, 'Glandular physiology and therapy: the adrenal cortex', J. Am. med. Ass., 1935, 104: 2177-82, quote on p. 2182.

${ }^{15}$ Arthur Grollman, The adrenals, Baltimore, Williams and Wilkins, 1936; S W Britton and $H$ Silvette, 'On the function of the adrenal
}

cortex: general, carbohydrate and circulatory theories', Am. J. Physiol., 1934, 107: 190-206; J J Pfiffner, W W Swingle and $H$ M Vars, 'The cortical hormone requirement of the adrenalectomized dog, with special reference to a method of assay', J. Biol. Chem., 1934, 104: 701-16; D J Ingle, 'Work capacity of the adrenalectomized rat treated with cortin', Am. J. Physiol., 1936, 116: 622-5; Kendall, op. cit., note 6 above, ch. 7. For an example of the patents Reichstein assigned to Organon, see 'Hormone compositions', German patent 656, 785 of 19 February 1938, cited in Chemical Abstracts 1938, 32: 4287.4 . 


\section{Nicolas Rasmussen}

initially to controversy over the true role of "the hormone" of the adrenal cortex. However, in the mid-1930s, the dispute over whether cortin was a "general tissue hormone" stimulating all cell types (as Hartman thought), or a hormone specifically controlling the balance of fluid and mineral electrolytes in tissue, or a hormone specifically regulating carbohydrate metabolism, began to give way to a realization that the adrenal cortex might control a variety of distinct physiological functions through several different hormones. In 1937 most attention was focused on the effects of cortical hormones on mineral metabolism (i.e. sodium and potassium in blood and other fluids) and its influence on circulatory collapse through fluid loss. Indeed, at a Cold Spring Harbor symposium that year all the major players, including Kendall, seemed prepared to accept that the adrenal cortex's influence on carbohydrate metabolism was merely a secondary effect of cortin's influence on minerals, or else the effect of another cortical hormone not essential for life. The one dissenter still insisting on the primacy of carbohydrate metabolism, and particularly the dependence of blood glucose and glycogen stores on cortical activity, the physiologist S W Britton of the University of Virginia medical school, met with general scepticism there. A key reason for this scepticism lay in the failure of cortical extract to produce diabetes-like conditions in animals both adrenalectomized and pancreatectomized (which, paradoxically, appeared to be spared diabetes by the absence of the adrenals). However, later in 1937, the group of the Yale physiologist Cyril Long was finally able to reproduce diabetes in such adrenalectomized-pancreatectomized animals by using stronger extracts obtained from Kendall. Evidence now supported a crucial role for the cortical hormone (or one of these hormones) in carbohydrate metabolism. ${ }^{16}$

In that same year, 1937, Reichstein stunned his competitors with a barrage of papers describing a variety of active compounds isolated from extracts provided by Organon, one of which he dubbed "corticosterone" in the expectation that the hormone, which affected sugar as well as mineral metabolism to some extent, was either Hartman's long-sought cortin or a close relative. His group also achieved synthesis of the related compound desoxycorticosterone, with a much higher activity on mineral metabolism than his corticosterone, by a commercially practical method. Clinical trials soon demonstrated that desoxycorticosterone did effectively maintain the life of Addison's patients in the same way as dietary control of minerals, but did not relieve lassitude and other symptoms associated with carbohydrate metabolism. Together with Long's results, these findings left little doubt that the hormones of the adrenal cortex active in mineral metabolism and in energy metabolism were distinct. And, since desoxycorticosterone did not fulfil this other, energy-related role of the cortex, another hormone drug still remained to be developed. Presumably this elusive hormone, active in regulating carbohydrate metabolism, would be a

\footnotetext{
${ }^{16}$ See articles and discussions on adrenal hormones in Cold Spring Harbor Symp. Quant. Biol., 1937, 5, especially S W Britton and $H$ Silvette, 'The adrenal cortex and carbohydrate metabolism', pp. 357-61. C N H Long, 'The influence of the pituitary
}

and adrenal glands upon pancreatic diabetes', Harvey Lect., 1936-37, 32: 194-228;

F D W Lukens and F C Dohan, 'The relation of the adrenal cortex to experimental diabetes: further observations', Endocrinology, 1938, 22: $51-8$. 
compound with an oxygen on carbon 11 of the steroid nucleus, like Reichstein's corticosterone and the cortical hormone Kendall called Compound E. ${ }^{17}$

At this stage, however, Kendall's closest American competitors seem to have accepted defeat in the face of Reichstein's chemical prowess, Pfiffner departing Columbia for an industrial position at Parke-Davis and Wintersteiner for one at Squibb. This left Kendall, in 1938, Reichstein's major academic opponent in the contest to identify and produce the cortical hormone responsible for carbohydrate metabolism. Reichstein was trying to synthesize his corticosterone, and presumably was well advanced in this effort. But Kendall did not share Reichstein's opinion that corticosterone, the same substance that Kendall called Compound B, was the chief adrenal hormone affecting carbohydrate metabolism. The sense that Reichstein was backing the wrong horse, together with information leading him to believe that Reichstein would not be able to maintain the pace of his work on natural cortical hormones because Organon would not be continuing to supply him with extracts so generously, gave Kendall enough confidence to continue his focused quest for Compound $\mathrm{E}$-his best guess as the cortical hormone regulating carbohydrate metabolism. This was the hormone which enhanced, at least in experimental animals made deficient in adrenal function, the capacity of muscles to perform work and the production of body heat in response to cold, which made respiration more efficient, and which possibly could combat shock through an effect on capillary oxygen exchange (as well as through whatever mineral activity the hormone might possess). ${ }^{18}$

\footnotetext{
${ }^{17}$ For some of Reichstein's publications at this time, see P de Fremery, Ernst Laqueur, Tadeus Reichstein, R W Spanhoff, I E Uyldert, 'Corticosteron, a crystallized compound with the biological activity of the adrenal-cortical hormone', Nature, 1937, 139: 26; Tadeus Reichstein, F Verzar, and L Laszt, 'Activity of corticosteron in the glucose test in rats', Nature, 1937, 139: 331; Marguerite Steiger and Tadeus Reichstein, 'Partial synthesis of a crystallized compound with the biological activity of the adrenal-cortical Hormone', Nature, 1937, 139: 925-6; Tadeus Reichstein, 'Constituents of the adrenal cortex. X. corticosterone', Helvetica Chimica Acta, 1937, 20: 953-69; Marguerite Steiger and Tadeus Reichstein, 'Chemical structure of corticosterone', Nature, 1938, 141: 202. For clinical results with desoxycorticosterone, see S Levy Simpson, 'The use of synthetic desoxycorticosterone acetate in Addison's disease', Lancet, 1938, ii: 557-8; E P McCullagh, 'Sodium and chloride retention in Addison's disease treated with desoxycorticosterone acetate', Cleveland Clin. $Q$, 1939, 6: 105-8; G W Thorn, R P Howard, K Emerson, Jr, and $\mathrm{W} M$ Firor, 'The treatment of Addison's disease with pellets of crystalline cortical hormone (synthetic desoxy-corticosterone acetate) implanted subcutaneously', Bull. Johns
}

Hopkins Hosp., 1939, 64: 339-65; H W Dryerre, 'The effect of desoxycorticosterone acetate and cortin on salt elimination in Addison's disease', Br. med. J., 1939, i: 971-3; J W Ferrebee,

C Ragan, D W Atchley, and R F Loeb, 'Desoxycorticosterone esters, certain effects in the treatment of Addison's disease', J. Am. med. Ass., 1939, 113: 1725-31. For some of Kendall's views of the relation of adrenal hormone structure and function at this time, see E C Kendall, 'Chemical studies of the adrenal cortex: the structures of compounds C, D, E, F, and G', J. Biol. Chem., 1938, 124: 459-74.

${ }^{18}$ Kendall, op. cit., note 6 above, chs 7-8. On oxygen consumption and muscle work see Ingle, op. cit., note 15 above; F A Hitchcock, R C Grubbs, and F A Hartman, 'The effect of cortical extract upon oxygen consumption of normal human beings', Am. J. Physiol., 1938, 121: 542-8; V Missiuro, D B Dill, and H T Edwards, 'Effects of cortical extract in rest and work', Am. J. Physiol., 1938, 121: 549-54; D J Ingle, 'The work-performance of hypophysectomized rats treated with cortin', Am. J. Physiol., 1938, 122: 302-5. On heat generation, see S M Horvath, F A Hitchcock, and F A Hartman, 'Response to cold after reduction of adrenal tissue', Am. J. Physiol., 1938, 121: 178-84; S M Horvath, 'Response to cold 


\section{Nicolas Rasmussen}

\section{Hormones at War}

Physiological properties like these carried medical implications which, with the fall of France in May 1940 and the escalation of the air war over Britain, suddenly took on great military significance. In October 1940, the National Research Council (NRC) Committee on Aviation Medicine was formed to advise the United States military, one of many such committees through which the United States government enlisted the aid of scientists to advise the military. Among the first investigations initiated by this Committee was one led by George Thorn, then an energetic young endocrinologist and clinical researcher at Johns Hopkins, to follow up on early reports of the adrenal gland's involvement in adaptation to high altitude. Thorn found that in humans and animals made to perform prolonged work in low-oxygen environments, blood sugar increased after several hours and performance was therefore maintained, whereas no such response occurred in adrenalectomized animals (consistent with prior results that animals living in low oxygen atmospheres had hypertrophied adrenal glands). This suggested that adrenal hormones affecting carbohydrate metabolism were a key factor in the adrenal gland's role in adaptation to high altitude. And high altitude was an absolutely crucial factor in the air war, as improved aircraft technology and the demands of aerial combat were suddenly thrusting large numbers of pilots to unprecedented heights. As one officer studying the problems (fatigue, vision impairment, reflex slowing, etc.) arising from pilot exposure to cold and low oxygen conditions of high altitudes aptly put it, "the machine has far outstripped the man" in aviation. ${ }^{19}$

In May 1941, a secret conference of leading endocrinologists and physiologists was convened by the NRC at Yale to discuss the military potential of adrenal research. John Fulton, a member of the Committee on Aviation Medicine, explained the circumstances leading to this meeting in his introductory remarks:

Dr. Thorn submitted his first report on January 15, 1941 ... Meanwhile unconfirmed rumours were being received from abroad that severe cases of flying stress among Germans and RAF were being encountered, in which an Addison-like syndrome has appeared accompanied by pallor, general malaise, fatigability, weakness etc. At about the same time it was learned that the German Air Force, and possibly also the English, were using adrenal cortical hormones to counteract fatigue, and possibly also in the treatment of flying stress ...

following double adrenalectomy', Endocrinology, 1938, 23: 223-7. On shock, see W W Swingle, W M Parkins, A R Taylor and H W Hays, 'The direct effect of cortical hormone on blood pressure in shock induced by intestinal manipulation', Proc. Soc. exp. Biol. Med., 1937, 37: 601-4; idem, 'The effect of cortical hormone upon circulatory collapse of adrenalin shock', Am. J. Physiol., 1938, 123: 668-76; idem, 'A study of the circulatory failure and shock following trauma to the healthy, vigorous,

adrenalectomized dog', Am. J. Physiol., 1938, 124: 22-9.

\footnotetext{
${ }^{19}$ Captain Charles Stephenson, minutes of OSRD Committee on Medical Research (CMR) meeting, 4-8 September 1941 , pp. 40-41, box 12 , folder 26, A N Richards Papers, University of Pennsyvania Archives collection UPT50/R514 (hereafter, Richards Papers). Minutes of the National Research Council Division of Medical Sciences conference on the adrenal cortical hormones in relation to medical defense, Yale School of Medicine, 16-18 May 1941, Washington, Office of War Information, 1941 (available in the book collection of the National Library of Medicine, Bethesda, MD).
} 
A week or two ago, we had a confidential report from Buenos Aires that the German Government had just purchased 50 tons of adrenal tissue from the Argentine, which is being shipped to Germany via Japan. We have, therefore, felt impelled to take energetic steps to see in what direction adrenal extract may be useful to the aviator. ${ }^{20}$

Given the state of physiological knowledge about adrenal hormones, coinciding with the early successes of Germany's Blitzkrieg and rampant speculations about the secret weapons enabling it, tales of Nazis shipping adrenal glands by U-boat for use by their pilots were understandably greeted with alarm rather than scepticism (illfounded though those tales later proved to be). In September 1941 the United States' newly established wartime agency for biomedical research, the Committee on Medical Research (CMR) of Vannevar Bush's Office of Scientific Research and Development (OSRD), took over much of the work of the Committee on Aviation Medicine (which now acted, like many other NRC committees, in an advisory role to the OSRD). Cortical steroids, and Kendall's Compound $\mathrm{E}$ in particular, became one of the agency's top life science R \& D targets for co-ordinated large-scale research effort, along with penicillin, anti-malarial drugs, and the development of substitutes for whole blood transfusions. ${ }^{21}$

In early October 1941, at the request of CMR chief Alfred Newton Richards, his friend William Mansfield Clark, an eminent biochemist trusted by industry and respected by academics (and chair of the NRC Committee on Chemistry), organized a conference of the American researchers most closely involved in the development of adrenal steroid hormones as drugs in order to assess the current status and prospects. Attending were Kendall, Louis Fieser from Harvard, Everett Wallis from Princeton, as well as Wintersteiner from Squibb and Pfiffner from Parke-Davis. All these biochemists and endocrinologists played their cards close to their chests, but

\footnotetext{
${ }^{20} \mathrm{John}$ Fulton, in Minutes, note 19 above, p. 2. The faulty intelligence report on German gland-smuggling has achieved mythic status among steroid biochemists. It has been attributed to the Polish underground (see Arthur J Birch, 'Steroid hormones and the Luftwaffe', Steroids, 1992, 57: 363-77), and has also been said, on the basis of slightly more direct evidence, to have emerged from the capture of a German submarine en route from Argentina with a load of incorrectly identified liver, actually intended for vitamin B12 research (see Louis F Fieser, The scientific method: a personal account of unusual projects in war and peace, New York, Reinhold, 1964, pp. 159-62). I am aware of no evidence on the source of the Allied intelligence more reliable than these apocryphal stories.

${ }^{21}$ CMR meeting minutes, 11 Sept. 1941, folder 28, box 12, Richards Papers. On penicillin see Jeffrey Sturchio, 'Chemistry in action: penicillin production in World War II', Today's Chemist, Feb. 1988, pp. 20-2, 35-6; Peter Neushul, 'Science, government, and the mass production of
}

penicillin', J. Hist. Med. Allied Sci., 1993, 48: 371-95. On the role of NRC committees in the penicillin and other CMR projects during (and indeed, after) the war, see Harry Marks, The progress of experiment: science and therapeutic reform in the United States, 1900-1990, Cambridge University Press, 1997, ch. 4, and passim. On blood substitutes, see Creager, op. cit., note 3 above. For comprehensive treatment of medical research under OSRD auspices, see E C Andrus, D W Bronk, G A Carden, Jr, C S Keefer, J S Lockwood, $\mathrm{J}$ T Wearn, and M C Winternitz (eds), Advances in military medicine, 2 vols, Boston, Little, Brown, 1948 - although this source covers very little of the cortical steroid research, which at the time of writing was considered a failure. On Bush and the OSRD in general, see Dupree, op. cit., note 3 above; J P Baxter, Scientists against time, Boston, Little, Brown, 1946; Irvin Stewart, Organizing scientific research for war, Boston, Little, Brown, 1948; G Pascal Zachary, Endless frontier: Vannevar Bush, engineer of the American century, New York, Free Press, 1997. 


\section{Nicolas Rasmussen}

they agreed that Clark should receive full progress reports, including proprietary knowledge, from all research teams and to decide when one of them had progressed to the point where the others needed to be informed and redirected in order to prevent needless duplication of effort. The group also concurred that the supply of adrenal glands was insufficient to meet any but research needs, that the problem of synthesizing a substance with an oxygen at carbon 11 of the steroid nucleus was the key to making Compound $\mathrm{E}$ available on a commercial scale, and that they would make work on this synthetic problem a top priority. ${ }^{22}$

Clark and Richards immediately began organizing more chemists to pursue the synthetic production of Compound E (as described below), and in late 1941 the CMR also initiated physiological research contracts on adrenal hormones, many picking up work begun under NRC Aviation Medicine auspices. Gerald Evans of the University of Minnesota studied the impact of prolonged anoxia in intact animals (especially mice), in particular carbohydrate metabolism, temperature change, and morphological change in the adrenals, and also modifications of these impacts through treatment with adrenal extracts. Thorn undertook studies of carbohydrate metabolism and low pressure tolerance in a variety of experimental animals, some without adrenal glands and some normal. Hartman investigated the distinct roles of low atmospheric pressure and low oxygen on the adaptive responses of normal animals to altitude, especially those mediated by the adrenals. Henry Ricketts of the University of Chicago similarly studied the distinct effects of anoxia and low pressure, both prolonged and intermittent, on physiological changes in various organs of normal animals. Rueben Gustavson of the University of Colorado tested the effect of a wide range of steroids, including testosterone and estrogens, on the tolerance of rats to low-oxygen, high-nitrogen atmosphere. E S Sundstroem of the University of California tested the effects of intermittent and sustained anoxia on normal animals' adaptation mechanism to high altitude, especially those involving the adrenals, and the impact of adrenal extract treatments on these adaptations. And Herbert Evans of the University of California adapted his existing research programme to the war, studying the effects of his recently purified adrenocorticotropic hormone, which the brain secretes and which stimulates the adrenal cortex, on carbohydrate metabolism at various atmospheric pressures. All of these projects were aimed at learning whether treatment of aviators with adrenal cortex hormones would increase their tolerance for high altitude. In addition, several contracts with physiologists were initiated to investigate whether cortical hormones counteract traumatic or surgical shock. ${ }^{23}$ All this research was intended to assess the utility to the military of Compound $\mathrm{E}$, and thus the probable wartime demand for the drug, if it proved technically and economically feasible to manufacture in quantity.

\footnotetext{
${ }^{22}$ W M Clark, 7 Oct. 1941, 'Brief of the Conference on Cortical Substance E', box 9, folder 'Adrenal Cortex', U. S. National Archives, Record Group 227, Entry 165 (hereafter, USNA 227/165).
}

\footnotetext{
${ }^{23}$ See information sheets for OEM-cmr contracts $20,43,60,64,74,113,133,134$, and 174 , carton 12 , folder 51 , Richards Papers.
} 


\section{Steroids in Arms}

Making the drug available in quantity would be the job of chemists and biochemists with talents in synthetic work. Kendall quickly took a number of actions to consolidate his leadership position in what was clearly going to become an even more crowded field. Two weeks after the first chemists' meeting on cortical steroids, Kendall informed Richards that he had successfully synthesized a key intermediate to Compound $\mathrm{E}$ and asked if the OSRD had any interest in claiming an intellectual property stake in this invention (as was typical in CMR projects). Kendall was told that since he had made his invention without government funding, patenting it would be his decision alone. A meeting with Vannevar Bush and the National Academy president Frank Jewett was immediately arranged in New York, whence Kendall flew directly from Washington. There, Bush suggested that the Research Corporation might be the best institution to manage Kendall's new patent. This non-profit agency existed to manage patents arising from academic-industrialist collaborations, finding industrial licensees for patents and funnelling royalties back to fields and to researchers specified by the research institutions and firms involved, an arms-length method allowing universities and other scientific institutions to draw financial benefits from the fruits of their research without having to commercialize the products themselves. Bush was perhaps thinking of the Research Corporation's recent handling of vitamin B patents, licensed to the Merck pharmaceutical house and made available to medicine by the firm, to contemporary acclaim. ${ }^{24}$

In any event, Bush arranged a meeting that same evening between Kendall and the Research Corporation's President Howard Poillon. A full weekend of meetings with lawyers, business executives and research managers, and bureaucrats in New York ensued. By the time Kendall returned to Minnesota the following Wednesday, less than a week after telling Richards of his new results, a bargain had formally been struck wherein the Research Corporation would apply for and manage Kendall's patent (which was to be kept secret in the interest of national defence) in exchange for assignment of the patent and half of any royalties, the other half to go into Kendall's University of Minnesota "Thyroxine Fund". Because of established relations with the Merck corporation (and probably Kendall's preference for this firm over Parke-Davis, who were courting Kendall for his cortical hormones), Poillon had arranged that Merck would be the drug firm licensed to use Kendall's patents, and to assist him in further development of methods for Compound $E$ synthesis. This arrangement sealed, Kendall then tried to convince Clark that there was no good reason for the chemists working on cortical steroids ever to meet again, arguing that although the first meeting had been necessary to take stock, the group would never be able to work co-operatively because of commercial rivalry between Squibb, Parke-Davis, and Merck, along with "scientific competition" between Wallis, Fieser, and himself. Indeed, Kendall suggested that he had the problem well enough in hand so that no other chemists or companies (besides Merck) need be involved at

\footnotetext{
${ }^{24}$ For examples of the Research Corporation's mediation between academic life scientists and industry in the first half of the twentieth century, see C Weiner, 'Patenting and academic research: historical case studies', Science, Technology, and
}

Human Values, 1987, 12: 50-62, and Nicolas Rasmussen, 'The forgotten promise of thiamin: Merck, Caltech biologists, and plant hormones in a 1930s biotechnology project', J. Hist. Biol., 1999, 32: 245-61. 


\section{Nicolas Rasmussen}

all. Though unable to persuade the OSRD that he and Merck should be allowed to handle the project alone, Kendall did manage to keep his results secret from the other chemists and firms involved, convincing Clark not to reveal his starting material when he informed the others which Compound $\mathrm{E}$ intermediate Kendall had synthesized, since this would make the pathway specified in new patent application obvious. Kendall's argument was that if other chemists had to be involved by the OSRD in Compound E synthesis, they should all work independently of one another so that multiple approaches would be fully explored. Kendall's sympathy with corporate concerns over sharing proprietary information must have helped him avoid some of the conflicts commonly experienced by other academic scientists of his day arising from industrial sponsorship of their research. ${ }^{25}$

Thus through Kendall's initiative, supported by Bush and Richards, the other half-dozen academic chemists working on Compound $\mathrm{E}$ synthesis under government contracts were, like the drug firms, all blind to one another's activities, except insofar as the Chairman, Clark, deemed it necessary to pass information among them. In late 1941 and early 1942, six of Kendall's most formidable rivals among academic biochemists (Werner Bergmann at Yale, Britton at Virginia, Thomas Gallagher at Chicago, C R Noller at Stanford, plus Fieser and Wallis) were all given contracts to pursue the same objective, synthesis of his Compound E; also, Arthur Grollman (of Wake Forest) undertook a contract to search for substitutes for cortical steroids, that is, unrelated molecules with similar biological activity. ${ }^{26}$ The secrecy policy meant that nobody other than Merck, Kendall's chosen partner, would be able to build easily on Kendall's prior work to reach the common goal faster. One can appreciate Kendall's concern that government involvement might translate into dilution or appropriation of the scientific credit he hoped to win from synthesizing Compound $\mathrm{E}$ - not to mention economic rewards. On this latter score at least, Kendall was reassured that the academic researchers were bound by a standard clause in their CMR contracts waiving all rights to intellectual property acquired under contract projects, except at OSRD discretion. In contrast, the industrial participants in the project, which not only included Parke-Davis and Merck but also Schering (but not Squibb, which redirected its efforts to penicillin), took no money from the OSRD and thus were not hampered by government contracts. Likewise, Kendall himself was not prevented from taking patents (which would be assigned

\footnotetext{
${ }^{25}$ Clark, n.d. [c. 30 Oct. 1941] , 'Memorandum of Conference of Morning of October 24, 1941'; Kendall to Clark, 3 Nov. 1941; also Kendall to Clark, 24 Sept. 1941, all in folder 'Adrenal Cortex', box 9, USNA 227/165. On the contractual arrangements, see Howard Poillon to Kendall, 28 Nov. 1941, and Poillon, draft letter of understanding and draft patent assignment agreement re. U.S. patent application 420,486 of 28 Nov. 1941, 'Cortex Hormones and Process of Making Same', 28 Jan. 1942, both in older 'Research Corporation', box 8, Kendall Papers. For some other contemporary examples of American academic scientists collaborating with
}

\author{
industry, and the problems that could arise \\ from such arrangements, see John Servos, \\ 'The industrial relations of science: chemical \\ engineering at MIT, 1900-1939', Isis 1980, 71: \\ 531-59, and idem, 'The knowledge corporation: \\ A. A. Noyes and chemistry at Cal Tech, \\ 1915-1930', Ambix, 1976, 23: 175-86. \\ ${ }^{26}$ See information sheets for OEM-cmr \\ contracts $32,42,55,70,95,106$, and 168 , \\ folder 51, carton 12, Richards Papers. Fieser \\ soon became Kendall's ally, accepting a \\ consultancy role with Merck and exchanging \\ laboratory staff both with Kendall's Mayo \\ group and Merck.
}




\section{Steroids in Arms}

to the Research Corporation and licensed to Merck under the bargain he had just struck) on the results of his war work, since he took no government funding for his already self-financing, quasi-industrial project at Mayo. The drug firms were apparently comfortable with Kendall's arrangements but, not surprisingly, some of the academic chemists were frustrated. For instance, Gallagher of Chicago considered multiple independent efforts an inefficient arrangement attributable to Kendall's egotism. Nor was Kendall unduly handicapped by the veil of secrecy over the other chemists' actions that he had been so central in imposing; Merck's research director Randolph Major informed him when Wallis ordered an intermediate from Merck that was "quite different" from his own, and when Gallagher ordered one that Kendall also was using. ${ }^{27}$

By mid-1943 the results of the first year and a half of physiological contracts were available, and the military potential of Compound $E$ underwent an interim assessment by Richards and the CMR. The overall picture was one of equivocal and unimpressive evidence. The results of Thorn and Gerald Evans were rated highest in reliability by Richards, and were given the most weight. Among other things, Thorn confirmed that in monkeys and other animals, repeated exposure to anoxia and low pressure equivalent to $20,000-27,000$ feet of altitude, physiological adaptation was accompanied by enlargement of the adrenal glands. Thorn also found that the absolute ceiling (i.e. point at which death on average occurred) of normal rats exposed to low pressures equivalent to altitudes over 30,000 feet was indeed raised by Kendall's extract; however, similar improvements in altitude tolerance could be obtained simply by preconditioning animals in atmospheres equivalent to $18,000-26,000$ feet, suggesting that a training regimen might substitute for hormone treatments. Moreover, using rats on treadmills in low-oxygen conditions, Thorn found no significant increase in the "work capacity" of animals treated with Kendall's extracts (though this experiment was confounded by large variations in the individual rats' propensity to perform "work"). Evans discovered that the degree of enlargement of adrenal glands accompanying high-altitude conditioning did not correlate with the actual altitude tolerance of animals, throwing the central role of the adrenal in altitude adaptation into doubt. He also found that in dogs no adrenal extract treatments ameliorated the decline in motor and visual performance brought on by low atmospheric pressures, and that in mice Kendall's extract brought only a slight

\footnotetext{
${ }^{27}$ Major to Kendall, 3 Dec. 1941; Kendall to Major, 24 Dec. 1942; Major to Kendall, 7 March 1942; folder 'Merck and Company Correspondence 1941-42', carton 8, Kendall Papers. T F Gallagher to Clark, 11 March 1942, folder 'Adrenal Cortex', box 9, USNA 227/165. On Parke-Davis's and Schering's independent pursuit of cortical steroid synthesis during the war, see Poillon to Richards, 13 Nov. 1941, folder 'Research Corporation', carton 8, Kendall Papers; also see Fieser, op. cit., note 20 above. On intellectual property restrictions applying to OSRD CMR
}

contractors, see Clark to Richards, 9 Feb. 1942, folder 'Adrenal Cortex', box 9, USNA 227/165. Interestingly, the CMR contract patent provisions were generally more stringent than for other OSRD contracts; see Larry Owens, 'The counterproductive management of science in the Second World War: Vannevar Bush and the Office of Scientific Research and Development', Bus. Hist. Rev., 1994, 68: 515-76, and Nicolas Rasmussen, 'Of "small men", big science, and bigger business: the second world war and biomedical research in America', Minerva, 2002, 40 (2), forthcoming. 
improvement in altitude tolerance (though these latter results were confounded by the strong temperature dependence of absolute ceiling in mice). Together the whole set of results suggested that Compound $\mathrm{E}$ and related adrenal cortex hormones affecting carbohydrate metabolism would not improve pilot performance, and although hormone treatment might have some limited utility in preventing death at extreme high altitudes, the right training regimen would be at least as effective. Nor did the physiological experiments testing the possibility of using cortical steroid treatments to prevent shock yield promising results. Richards and the CMR effectively pulled the plug, discontinuing physiological research aimed at assessing the value of cortical steroid usage in the combat theatre (though the hormones continued to play a role in some other medical research projects, for example on convalescence and healing). The negative assessment of the military potential of the hormones was reflected in the declassification of the physiological research involving them, in late $1943 .{ }^{28}$

All the chemistry groups had been pursuing methods of synthesizing Kendall's Compound A from various sterol starting materials, since this steroid had carbohydrate metabolism activity like Compound $\mathrm{E}$ and similar, though simpler, structure. Presumably, Compound E would be easily synthesized from A, or by a related pathway, once this was developed. But by the spring of 1943, the chemists had made very limited progress in their quest to plant an oxygen on the carbon 11 summit of the steroid nucleus. With the shadow on the future of the synthetic projects cast by the findings of the physiologists, Mansfield Clark naturally inquired as to whether the CMR wanted the chemists' research to continue after June 1943. Richards discussed the matter with Bush, and replied that while specific chemical projects would have to be judged on a case-by-case basis, the CMR and Bush agreed that the effort to synthesize the cortical hormones should continue. The rationale for this decision is curious. As Richards put it in a letter to Clark:

It is obviously impossible to say with conviction that the problem is one of direct military significance. It is equally impossible to say that it is not. What I have said above [i.e. that chemical work should proceed] is based on the possibility that military significance may emerge and upon the conviction that the work as it is proceeding is definitely in the national interest. $^{29}$

Why the chemists' work was "definitely" in the national interest during wartime whether or not cortical hormones might have military applications is an intriguing question. Naturally, the hormones were intellectually interesting to a number of life scientists, but the OSRD's purpose was precisely to divert scientists away from purely intellectual goals, and toward wartime priorities. Rather than military or scientific interest in these hormones, the primary consideration behind continuation of the

\footnotetext{
${ }^{28}$ [Richards and C N H Long], n.d., 'Special Appraisal of Adrenal Projects in CAM', folder 'Adrenal Cortex', box 9, USNA 227/165. On shock, see W W Swingle, March 1943, 'Final Technical Progress Report', contract OEMcmr-5,
}

box 36, USNA 227/29. Louis Flexner, 'Reclassification of Aviation Medicine Reports', 28 Oct. 1943, folder 42, carton 12, Richards Papers.

${ }^{29}$ Richards to Clark, 1 May 1943, USNA 2271 165, box 9, folder 'Adrenal Cortex'. 
work might well have been protecting the position of the American pharmaceutical industry in the coming peace. Bush, active in industrial policy and experienced in consulting since his early career in electrical engineering, would have been as aware of the commercial importance of methods to produce a new class of drugs as Richards, longtime consultant to Merck. And there was no secret that Reichstein was forging ahead, backed by European drug firms. While most American firms did not actually begin advertising their post-war consumer product lines until mid-1944, the issue of the post-war economy would never be far from the minds of such urbane men, even while immersed in serving the nation's war effort.

At any rate, later in 1943 the chemists received the unwelcome news, via Clark from the Swiss firm CIBA (Reichstein's industrial partner after Holland fell under German occupation), that Reichstein had beaten them all in the race to synthesize Compound A. As Kendall put it, there were "whispers" and "raised eyebrows" that the cortical hormone biochemists had made so little headway in two years, while their counterparts working on penicillin and anti-malarials had all made such excellent progress. Most of the chemists on Clark's team (with the exception of Gallagher, who was making good progress by a route different from Kendall's) quickly discontinued their contract projects, as might be expected. But even in March 1944 Richards was willing to allow continuation of the synthetic projects despite a "growing disposition within the CMR to regard the prospects of practical usefulness from the adrenal cortex contracts as remote", asking Clark to reconfirm which synthetic projects he thought were especially worthwhile. ${ }^{30}$ The indefatigable Kendall had naturally soldiered on through Reichstein's triumph, and in January 1944 gleefully reported to his Research Corporation contacts that he had developed a new synthetic pathway to Compound A with up to 1000 times the yield of Reichstein's. Kendall passed his new method on to Merck immediately, and the firm set out to manufacture at least 5 grams of Compound $A$ so that there would be sufficient material to evaluate the hormone as a drug. Through the rest of 1944 Kendall continued at the Mayo to improve the Compound A method and to seek a pathway to Compound E, now under less favourable conditions as he became less able to protect his laboratory personnel from the draft, especially after Clark's chemical committee officially disbanded in mid-1944. He continued sharing detailed information with Merck chemists by mail, laboratory personnel were exchanged between Mayo and Rahway, and Kendall himself visited to consult with the firm in person. In late December 1944, Merck chemist Lewis Sarett, who had been working on the project since the beginning of the Mayo-Merck collaboration, surprised Kendall by achieving synthesis of Compound $\mathrm{E}$, albeit in small quantities and at low efficiency. The Merck chemists who had undertaken the large batch synthesis of Compound A by Kendall's method, Jacob van de Kamp and S M "Monty" Miller,

\footnotetext{
${ }^{30}$ Kendall, op. cit., note 6 above, p. 103. Richards to Clark, 18 March 1944, folder 'Adrenal Cortex', box 9, USNA 227/165; Hans Clarke to Charles Keefer, with attached Kendall memo, 4 April 1945, folder 'Kendall, E. C.', box 46, USNA 227/165. Gallagher's OSRD contract was
}

\author{
continued through March 1945, Wallis's was \\ continued to December 1944, and both Fieser's \\ and Bergmann's were continued only to June 1944; \\ see record sheets on contracts OEMcmr-42, \\ OEMcmr-32, OEMcmr-168, and OEMcmr-106 \\ respectively, folder 51, carton 12, Richards Papers.
}




\section{Nicolas Rasmussen}

impressed Kendall still more when at the end of 1945 they produced 97 grams of Compound $\mathrm{A}$ instead of the planned 5 grams, by efficiency improvements in several steps. ${ }^{31}$ Thus, as the war ended, Kendall seemed on the brink of reaching his long-time goal of making the pure cortical hormones he studied available as pharmaceuticals.

Clinical trials and further physiological experimentation ensued immediately at the start of 1946. Confident that Compound A, so similar to (though weaker than) his favoured Compound $\mathrm{E}$ in carbohydrate activity, would yield impressive results, Kendall organized a special symposium to present the findings at Atlantic City just before the annual meeting there of the Federation of American Societies for Experimental Society. A record of the exact proceedings of the symposium seems not to exist, but, judging by the researchers involved, reports were presented on the effectiveness of Compound A in counteracting bacterial toxins, in treating Addison's disease, and perhaps in other endocrine disorders. Whatever precisely was reported, the overall impression of those involved was entirely negative. One of Kendall's associates purportedly remarked to him immediately after the event that it should never have been allowed to happen, because now no drug company would be willing to invest in Compound E. ${ }^{32}$ But Sarett persevered through 1945 and 1946 and, incorporating process improvements made by Kendall and the other Merck chemists as he learned of them, in 1947 found an economical route to synthesize Compound E-that is, as it now was dubbed, "cortisone". Merck promptly set about producing a large batch, supplying the material for the famed 1948 clinical trial in which patients long crippled by rheumatoid arthritis walked (indeed, danced) with ease again, leading to the 1950 Nobel Prize to Kendall, along with Reichstein and Philip Hench, Kendall's rheumatologist colleague. The Research Corporation negotiated a patent pool among Kendall, Merck, CIBA, and other holders of rights to key steps in the industrial cortisone synthesis process so that the commercialization of the hormone could proceed. While cortisone itself was soon replaced by derivatives with fewer side-effects, the cortical steroids were a permanent benefit to medicine, and an important tool in the further elucidation of the endocrine system. ${ }^{33}$

\footnotetext{
${ }^{31}$ Kendall to Poillon, 15 Jan. 1944, folder 'Research Corporation', box 8, Kendall Papers. Kendall, op. cit., note 6 above, ch. 11 .

${ }^{32}$ Kendall, op. cit., note 6 above, ch. 11 . Kendall to Major, 11 Feb. 1946, 23 Feb. 1946, and 4 March 1946, all in folder 'Abbott Laboratories', carton 8, Kendall Papers. For work by participants probably close to that reported at Kendall's symposium, see Lena Lewis and Irvine Page, 'Method of assaying adrenal preparations for protective action against toxic material (typhoid vaccine)', FASEB Proc., 1946, 5: 163; Eleanor Venning and J S L Browne, 'Excretion of urinary corticoid hormones by man in health and disease', FASEB Proc., 1946, 5: 159.

${ }^{33}$ On Kendall and Sarrett's continuing work, see, for example, Kendall to Major, 1 April 1944;
}

Kendall to Major, 6 April 1944; Major to Kendall, 13 July 1944; van de Kamp to Kendall, 10 Aug. 1944; Kendall to Major, 15 Aug. 1944;

Kendall to van de Kamp, 2 Dec. 1944; Sarrett to Kendall, 13 Dec. 1944; all in folder 'Merck and Company Correspondence 1943-1944-1945', carton 8, Kendall Papers. On the patent situation, see, C O'Connor memo, 'Adrenal Hormones Meeting', 26 Dec. 1947, folder 'Merck and Company Reports on Current Research', carton 8, Kendall Papers; also Kendall, op. cit., note 6 above, ch. 13 . On the replacement of the first generation of cortical steroids due to sideeffects, see Thorn, 'Adrenal cortex', op. cit., note 5 above, and idem, 'The adrenal cortex. II. Clinical considerations', Johns Hopkins med. J., 1968, 123: 65-77. 
The anti-inflammatory properties which quickly made cortisone the archetypical post-war miracle drug had been discovered through Hench's clinical intuition, and the fact that such applications not been anticipated by endocrinologists studying Compound $\mathrm{E}$ in animal models certainly demonstrates the limits of laboratory-based drug development research. Intriguingly, however, the use of 1930s-style whole cortical extracts to boost strength and to combat mental stress and fatigue, the prewar market for the remedy which must have shaped pharmaceutical companies' expectations of the indications drugs like cortisone would acquire, continued into the 1970s, due mainly to a medical movement promoting the extracts as a cure for hypoglycaemia (which, according to this faction, was much more widespread than orthodox opinion held) ${ }^{34}$ Thus may the misbegotten dreams of master molecules die hard, particularly when they take such a perennially attractive form as a remedy bringing happiness and strength. But this is a story for another day.

\section{Conclusion}

The story of research on the hormones of the adrenal cortex well illustrates the degree to which, in the 1910s through the 1940s, hormones were taken to be mastercontrollers of life processes (in the case of these particular hormones, of respiratory efficiency, circulation, and a variety of neural functions). It also shows how much the harnessing of hormones was thought to offer medicine through mastery over these same processes, and how thoroughly the interest in practical applications could draw hormone researchers into intimate relationships with the pharmaceutical industry - relationships more than slightly resembling those decried by recent critics of molecular biologists' involvement with biotechnology firms. ${ }^{35}$ While, unlike some entrepreneurial biologists today, the hormone researchers of the early twentieth century generally did not personally grow rich from their patents, their corporate partners did, and their universities acquired income to support their activities. Kendall and his generation of endocrinological researchers drew money and material resources from industry to support their research, for which they exchanged the intellectual property rights they acquired in the course of their scientific investigations. These resources could be crucial for the advancement of their endocrinological

\footnotetext{
${ }^{34}$ For the enthusiastic reception of cortisone, see G Hetenyi, Jr, and J Karsh, 'Cortisone therapy: a challenge to academic medicine in 1949-1952', Perspect. Biol. Med., 1997, 40: 426-39; Harry Marks, 'Cortisone, 1949: a year in the political life of a drug', Bull. Hist. Med., 1992, 66: 419-39; and David Cantor, 'Cortisone and the politics of drama, 1949-1955', in J V Pickstone (ed.), Medical innovations in historical perspective, New York, St Martin's Press, 1992, pp. 165-84. For the post-war notoriety of cortical extracts, see, for example, 'Medical groups decry useless injections for nervous women', J. Am. med. Ass., 1973, 223: 682; and Joel Yager and R T Young, 'Non-hypoglycemia
}

is an epidemic condition', N. Engl. J. Med., 1974, 291: 907-8.

${ }^{35}$ Edward E Yoxen, The gene business: who should control biotechnology?, New York, Oxford University Press, 1983; Martin Kenney,

Biotechnology: the university-industrial complex, New Haven, Yale University Press, 1986; idem, 'Biotechnology and the creation of a new economic space', in Thackray (ed.), op. cit., note 1 above, pp. 131-43; Sheldon Krimsky, Biotechnics and society: the rise of industrial genetics, New York, Praeger, 1991; James R Brown, 'Privatizing the university: the new tragedy of the commons', Science, 2000, 290: 1701-2. See also Rasmussen, op. cit., note 2 above. 


\section{Nicolas Rasmussen}

research, costly and pressed for time by competition as their research programmes often were. Furthermore, industrial partnerships represented much more than simply resources for scientists pursuing knowledge of hormones, if their ambitions also included the introduction of their hormone discoveries into medical practice. To this end, endocrinology researchers had to become active partners in the commercial endeavours of their drug company collaborators, acting in their partner's interests with respect to factors affecting the firm's likely return on investment from hormone drug development, such as avoiding patent obstacles and pursuing maximal yields in the hormone preparation methods they were developing, and maintaining the secrecy of unpatentable proprietary information. ${ }^{36}$ And as Kendall's 1950 Nobel Prize reminds us, such work was not regarded as scientifically inferior because of its commercial dimensions, according to the values of his day. However, one might well observe that Kendall was a man of his era, and that his day was passing both literally (in that he would retire within a year of receiving the Nobel prize) and figuratively. He was among the last of his particular breed of entrepreneur.

Kendall's style of entrepreneurship had served him well in the Depression. It will also be evident from this story that it served him well enough during the Second World War, government intervention causing no major interruption in his industriallyoriented hormone discovery and drug development programme. Perhaps the OSRD forced Kendall to take on a corporate partner earlier in the game than he would have in peacetime, but Merck was an ideal match for him, and he suffered no crucial loss either of intellectual property or personal scientific credit as a result of government involvement in his cortical hormone work. The discontinuation of OSRD interest in his project caused even less interruption than its initiation. This finding of continuity through the war comes as something of a surprise if one expects, following many historians of science, that government management of science during wartime, in the United States particularly by the OSRD, suddenly transformed academic physical and biomedical sciences alike into the "Big Science"-richly funded, bureaucratized, technology-intensive, large in scale, and mission-oriented in style (often with a mission related to military or industrial applications) - that became so widespread after the war. This is not the place for a general assessment of the impact of wartime government patronage on life sciences in America, but Kendall's experience suggests that in fields where "Big Science" was already the rule through pre-war industrial sponsorship, agencies like the OSRD did little beyond allowing the competitive and productive forces already in play to take their course. Certainly Bush, Richards, and Clark were solicitous of the interests of Kendall and his industrial partners at every stage of the game, from their initial decision to let

\footnotetext{
${ }^{36}$ Kendall plainly shows all of these behaviours, for instance in his continuing research during 1943-44 on Compound A synthesis in pursuit of a different pathway, with higher yields, than that already developed (and patented) by Reichstein, and by his continued pursuit in 1945 of a Compound E synthesis
}

pathway with higher yields than that obtained by his collaborator Sarett. His concern to keep proprietary information secret from competitors was evinced by his successful efforts to limit information exchange among the OSRD collaborators on Compound E, described above. See Kendall, op. cit., note 6 above, ch. 11 . 
Kendall keep his patent application and other competitive information secret from other participants in the cortical steroid project, to their decision to allow Kendall the special privileges of a CMR contractor well beyond their mid-1943 conclusion that his hormones were unlikely to contribute to the war effort. Perhaps this should come as no surprise, since Bush was no socialist, and accomplishing national goals through the voluntary participation of private enterprise was his agency's essential strategy for recruiting science to the war effort. ${ }^{37}$

Though Kendall's cortical hormone work through the 1930s and 1940s illustrates how well established industrially-sponsored "Big Science" already was before the war in certain fields of biomedical research holding promise for pharmaceutical companies, in the post-war era the expansion of government patronage did bring a real change to the character of research even in these precocious fields. In 1950, when the National Science Foundation was finally established in the United States after years of debate on its exact form, the annual research budget of the National Institutes of Health had already exceeded the entire wartime budget of the CMR and was doubling every year or two. ${ }^{38}$ In this new era, federal funding for basic research quickly overshadowed what was available from private enterprise, and the industrial collaborations that allowed Kendall to do technology-rich and labourintensive work on a grand scale through three decades became unnecessary for the biomedical generation that followed his. The rising influence of government science agencies in the 1950s brought the peer-reviewed grant to dominance and, until recently, discouraged industrial collaborations, at least in biomedical science. It is to the post-war science agencies that we must look to explain some aspects of the discontinuities that appear, in hindsight, to have been brought to science by the Second World War. Much historical work remains to be done on these agencies and their influence in the life sciences in the post-war period. ${ }^{39}$ But notwithstanding these changes that made peer-reviewed government funding the rule, and despite the eclipse of the hormone by the gene in the second half of the twentieth century, we must recall that earlier age when entrepreneurial life scientists like Kendall reigned

\footnotetext{
${ }^{37}$ For a fuller treatment of life science during the war, see Rasmussen, op. cit. note 27 above. For other sources on American science and the Second World War, see Owens, op. cit., note 27 above; David Hart, Forged consensus: science, technology, and economic policy in the United States, 1921-1953, Princeton University Press, 1998, ch. 5; and also sources cited in note 3 above.

${ }^{38}$ S P Strickland, Politics, science, and dread disease: a short history of United States medical research policy, Cambridge, MA, Harvard University Press, 1972; idem, The story of the NIH grants programs, Lanham, MD, University Press of America, 1988; D M Fox, 'The politics of the NIH extramural research program, 1937-1950', J. Hist. Med. Allied Sci., 1987, 42: 447-66. For a small sample of the literature on the genesis of NSF, see Daniel
}

Kevles, 'The National Science Foundation and the debate over postwar research policy; a political interpretation of "Science the Endless Frontier"', Isis, 1977, 68: 5-26; Nathan Reingold, 'Vannevar Bush's new deal for research: or, the triumph of the old order', Hist. Stud. phys. biol. Sci., 1987, 17: 299-344; idem, 'Choosing the future: the U.S. research community, 1944-1946', Hist. Stud. phys. biol. Sci., 1995, 25: 301-28; Daniel Kleinman, 'Layers of interests, layers of influence: business and the genesis of the National Science Foundation', Science, Technology, and Human Values, 1994, 19 (3): 259-82.

${ }^{39}$ See, however, Toby Appel, Shaping biology: the National Science Foundation and American biological research, 1945-1975, Baltimore, Johns Hopkins University Press, 2000. More work of this kind is much to be desired. 
supreme-an age which included the war years themselves - if we wish to learn any lessons that this past might teach us about our current preoccupations with today's master molecules. The first such lesson might be that industrial collaborations do not always represent an insuperable obstacle to biomedical research of the highest calibre. 